\title{
Temperature and Strain Rate Dependences of Yield Stress of an Al-Li-Cu-Mg-Zr Alloy*
}

\author{
By Minoru Furukawa**, Yasuhiro Miura*** and Minoru Nemoto***
}

\begin{abstract}
The effects of testing temperature and strain rate on the yield stress of an aged $\mathrm{Al}-\mathrm{Li}-\mathrm{Cu}-\mathrm{Mg}-\mathrm{Zr}$ alloy have been investigated at temperatures between $77 \mathrm{~K}$ and $523 \mathrm{~K}$ and over the strain rate range of $1.77 \times 10^{-4} \mathrm{~s}^{-1}$ to $1.77 \times 10^{-2} \mathrm{~s}^{-1}$. The deformation-induced dislocation structure was examined by transmission electron microscopy. In the specimens as quenched, under-aged or aged nearly to the peak strength, dislocations move as pairs when the alloy is deformed at $290 \mathrm{~K}$. In the over-aged specimens, dislocations move as single dislocations and tangle during deformation. For the alloy under-aged or aged nearly to its peak strength, the yield stress decreases with increasing testing temperature from $77 \mathrm{~K}$ to $290 \mathrm{~K}$, and the positive temperature dependence of yield stress is observed in the temperature range from $290 \mathrm{~K}$ to $450 \mathrm{~K}$. Within this temperature range, dislocations move in pairs cutting the $\delta^{\prime}-\mathrm{L} 1_{2}$ ordered particles. The yield stress decreases with increasing testing temperature above $450 \mathrm{~K}$, and dislocations move as single dislocations. The serrated yielding characteristic is observed for specimens as quenched, under-aged and aged nearly to the peak strength. At testing temperatures below $423 \mathrm{~K}$, the yield stress is almost independent of strain rate at peak-aged and over-aged stages. For the under-aged stage, the strain rate dependence of the yield stress is negative at the temperature range within which the positive temperature dependence of yield stress appears. At testing temperatures above $473 \mathrm{~K}$, the yield stress increases linearly with the logarithm of strain rate at any aging stage, and the strain rate dependence increases with increasing testing temperature.
\end{abstract}

(Received March 13, 1987)

Keywords: aluminum-lithium-copper-magnesium-zirconium alloy, ordered precipitate, precipitation hardening, solid-solution hardening, serrated stress-strain curve, mechanical property, temperature dependence, strain-rate dependence, super-dislocation, transmission electron microscopy

\section{Introduction}

Over the last few years much work has been done on aluminum alloys containing lithium. The Al-Li alloys are attractive for aerospace applications because of their high strength and high elastic modulus ${ }^{(1)}$. The specific strength and specific modulus of $\mathrm{Al}-\mathrm{Li}-\mathrm{Cu}-\mathrm{Mg}-\mathrm{Zr}$ alloy (registered as 8090) are approximately $10 \%$ superior to those of 7075 which is the target alloy for the first generation $\mathrm{Al}-\mathrm{Li}$ alloys $^{(2)-(4)}$.

The Al-Li alloys are appreciably hardened

* This paper was originally published in Japanese in $\mathbf{J}$. Japan Inst. Metals, 50 (1986), 961.

** Department of Technology, Faculty of Education, Fukuoka University of Education, Munakata 81141, Japan.

*** Department of Metallurgy, Faculty of Engineering, Kyushu University, Fukuoka 812, Japan. by the precipitation of $\delta^{\prime}$-phase which is a quasi-equilibrium phase of the $\mathrm{L1}_{2}$ ordered structure. It is known that the strength of the $\mathrm{L}_{2}$ ordered phase often increases with increasing temperature to a peak value at an elevated temperature. This behavior is believed to be the main origin of the superior high temperature strength of various $\gamma^{\prime}$ hardened nickelbase superalloys ${ }^{(5)-(7)}$. The Al-Li alloys containing the $\delta^{\prime}-\mathrm{L}_{2}$ ordered phase are expected to show high strength at elevated temperatures because of this structural similarlity to the nickel-base superalloys. This aspect also makes the Al- $\mathrm{Li}$ alloys attractive for aerospace applications, since materials for aerospace structures are required to keep adequate strength over a wide range of temperature.

The microstructure of the $\mathrm{Al}-\mathrm{Li}-\mathrm{Cu}-\mathrm{Mg}-\mathrm{Zr}$ alloy is not simple. Various phases such as $\mathrm{S}^{\prime}\left(\mathrm{Al}_{2} \mathrm{CuMg}\right), \mathrm{T}_{1}\left(\mathrm{Al}_{2} \mathrm{CuLi}\right), \mathrm{Al}_{3} \mathrm{Zr}$ and $\delta(\mathrm{AlLi})$ in addition to $\delta^{\prime}$ are found to precipitate dur- 
ing artificial aging treatments ${ }^{(8)-(10)}$. Several other phases have also been detected in this alloy in the over-aged state ${ }^{(11)}$. The strengthening and deformation mechanisms of the alloy have not yet been adequately understood because of the complexity of this microstructure. The strength of the alloy at elevated temperatures has been studied by several investigators $^{(12)(13)}$. They have reported the effect of soaking and pre-stretching on the strength of the alloy at elevated temperatures from the practical viewpoint.

The purpose of the present work is to investigate the temperature and strain rate dependences of the strength of $\mathrm{Al}-\mathrm{Li}-\mathrm{Cu}-\mathrm{Mg}-$ $\mathrm{Zr}$ alloy having various microstructures in a temperature range between 77 and $523 \mathrm{~K}$, and to compare the strengthening and deformation mechanisms with those of the Al-Li binary alloy reported previously by the present authors $^{(14)-(17)}$.

\section{Experimental Procedure}

The compositions of the alloys used in the present investigation are given in Table 1 . The $\mathrm{Al}-\mathrm{Li}-\mathrm{Cu}-\mathrm{Mg}-\mathrm{Zr}$ alloy was prepared by Furukawa Aluminum, LTD. via melting in an argon atmosphere and was supplied in a $3 \mathrm{~mm}$ thick strip. Other alloys were prepared as reference alloys for comparison. The specimens of $3 \mathrm{~mm} \times 3 \mathrm{~mm} \times 4.7 \mathrm{~mm}$ were solution treated at $823 \mathrm{~K}$ for $1.08 \times 10^{4} \mathrm{~s}$ in glass capsules filled with argon to avoid the lithium loss during heat treatments ${ }^{(18)(19)}$, followed by quenching into iced water and aged at $443 \mathrm{~K}$ and $473 \mathrm{~K}$ for various periods.

The aged specimens were tested in compression at temperatures between 77 and $523 \mathrm{~K}$ with an Instron-type machine over a nominal strain rate range from $1.77 \times 10^{-4} \mathrm{~s}^{-1}$ to $1.77 \times 10^{-2} \mathrm{~s}^{-1}$. The compressive tests were per- formed at $77 \mathrm{~K}$ and $213 \mathrm{~K}$ in liquid nitrogen and in methyl alcohol containing dry ice, respectively. The compressive tests at temperatures above room temperature were performed in a silicon oil bath, and the tested specimens were immediately cooled into water.

Slices of $0.3 \mathrm{~mm}$ thick were taken from the specimens deformed approximately $3 \%$ by using a fine cutting machine, followed by polishing down to $0.15 \mathrm{~mm}$ in thickness on emery paper. Thin foils for transmission electron microscopy (TEM) were prepared using a modified twin-jet electropolishing apparatus ${ }^{(20)}$. The composition of electrolyte was $20 \%$ $\mathrm{HClO}_{4}$ and $80 \% \mathrm{C}_{2} \mathrm{H}_{5} \mathrm{OH}$. Microstructures and dislocation configurations were investigated by dark field transmission electron microscopy using a JEM-1000D high voltage electron microscope $(1000 \mathrm{kV})$ in HVEM Laboratory of Kyushu University.

\section{Experimental Results and Discussion}

\section{Age hardening and configuration of deformation induced dislocations}

Figure 1 shows optical microstructures of as quenched $\mathrm{Al}-\mathrm{Li}-\mathrm{Cu}-\mathrm{Mg}-\mathrm{Zr}$ (a), $\mathrm{Al}-3 \mathrm{Li}$ (b) and $\mathrm{Al}-3 \mathrm{Li}-0.1 \mathrm{Zr}$ (c) alloys, respectively. A TEM study easily revealed that the $\mathrm{Al}-\mathrm{Li}-\mathrm{Cu}-$ $\mathrm{Mg}-\mathrm{Zr}$ alloy is unrecrystallized containing subgrains of $2-10 \mu \mathrm{m}$ in size (Fig. 2). In the Al-Li binary alloy (Fig. 1(b)), an equiaxed grain structure with a grain size of $200-400 \mu \mathrm{m}$ is formed by cold rolling and subsequent solution treatment. An unrecrystallized grain structure is also observed in the $\mathrm{Al}-\mathrm{Li}$ alloy containing $0.1 \% \mathrm{Zr}$ (Fig. 1(c)). However, the subgrain size in $\mathrm{Al}-\mathrm{Li}-\mathrm{Zr}$ alloy is several times larger than that in the $\mathrm{Al}-\mathrm{Li}-\mathrm{Cu}-\mathrm{Mg}-\mathrm{Zr}$ alloy.

Figure 3 shows the variation of yield stress $\left(0.2 \%\right.$ proof stress: $\left.\sigma_{0.2}\right)$ of the $\mathrm{Al}-\mathrm{Li}-\mathrm{Cu}-\mathrm{Mg}-$

Table 1 Chemical composition of specimens (mass\%).

\begin{tabular}{lccccccccccc}
\hline \hline & $\mathrm{Li}$ & $\mathrm{Cu}$ & $\mathrm{Mg}$ & $\mathrm{Zr}$ & $\mathrm{Si}$ & $\mathrm{Fe}$ & $\mathrm{Ti}$ & $\mathrm{Na}$ & $\mathrm{Mn}$ & $\mathrm{Cr}$ & $\mathrm{Al}$ \\
\hline $\mathrm{Al}-\mathrm{Li}-\mathrm{Cu}-\mathrm{Mg}-\mathrm{Zr}$ & 2.58 & 1.17 & 0.64 & 0.10 & 0.06 & 0.07 & 0.01 & 0.0027 & 0.00 & 0.00 & bal. \\
$\mathrm{Al}-\mathrm{Li}$ & 3.12 & & 0.0045 & & 0.029 & 0.0073 & & & & & bal. \\
$\mathrm{Al}-\mathrm{Li}-\mathrm{Zr}$ & 2.64 & & & 0.097 & & & & & & bal. \\
$\mathrm{Al}-\mathrm{Cu}-\mathrm{Mg}-\mathrm{Zr}$ & & 1.24 & 0.64 & 0.08 & & & & & & & bal. \\
\hline \hline
\end{tabular}



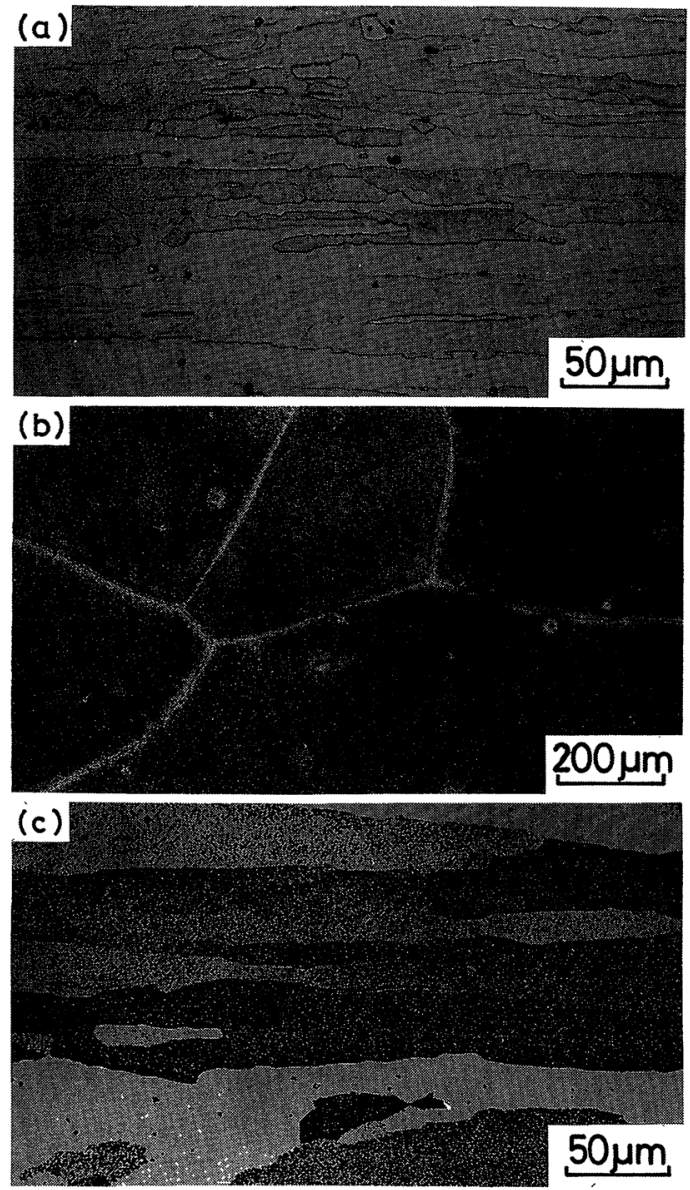

Fig. 1 Optical microstructures of as quenched (a) Al-Li$\mathrm{Cu}-\mathrm{Mg}-\mathrm{Zr}$, (b) $\mathrm{Al}-3.12$ mass\% $\% \mathrm{Li}$ and (c) $\mathrm{Al}-2.64$ mass $\% \mathrm{Li}-0.1$ mass $\% \mathrm{Zr}$ alloys.

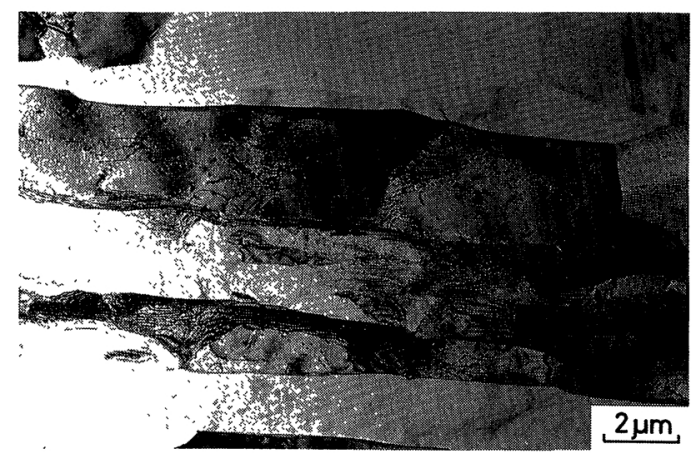

Fig. 2 Bright field image of as quenched $\mathrm{Al}-\mathrm{Li}-\mathrm{Cu}-\mathrm{Mg}-$ $\mathrm{Zr}$ alloy.

$\mathrm{Zr}$ alloy aged at $443 \mathrm{~K}$ and $473 \mathrm{~K}$ as a function of aging time. Dotted lines in the figure in-

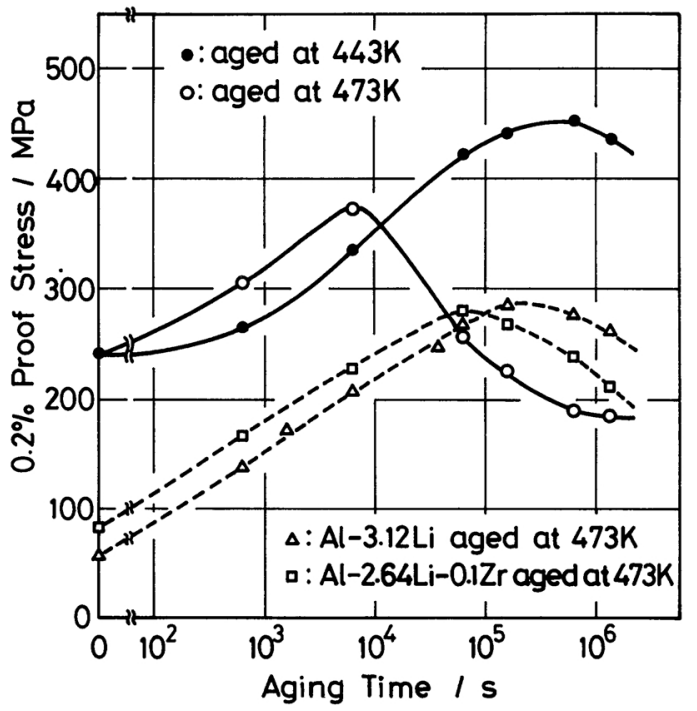

Fig. $3 \quad 0.2 \%$ proof stress vs aging time. Specimens were solution treated at $823 \mathrm{~K}$ for $1.08 \times 10^{4} \mathrm{~s}$, quenched into iced water and aged at $443 \mathrm{~K}$ and $473 \mathrm{~K}$. Dotted lines indicate $0.2 \%$ proof stress of $\mathrm{Al}-3.12$ mass $\% \mathrm{Li}$ and Al-2.64 mass\%Li-0.1 mass\%Zr alloys.

dicate the variations of yield stresses of the Al$\mathrm{Li}$ binary ${ }^{(14)}$ and $\mathrm{Al}-\mathrm{Li}-\mathrm{Zr}$ ternary alloys aged at $473 \mathrm{~K}$. The yield stress of the binary Al-Li alloy attains a maximum value by aging for about $2 \times 10^{5} \mathrm{~s}$ at $473 \mathrm{~K}$. On the other hand, the peak position of the aging curve for $\mathrm{Al}-\mathrm{Li}-$ $\mathrm{Zr}$ alloy shifts to the side of shorter aging time. The aging time necessary to attain the maximum strength for $\mathrm{Al}-\mathrm{Li}-\mathrm{Cu}-\mathrm{Mg}-\mathrm{Zr}$ alloy is the shortest of these alloys and the yield stress decreases abruptly by further aging. This aging characteristics of $\mathrm{Al}-\mathrm{Li}-\mathrm{Cu}-\mathrm{Mg}-\mathrm{Zr}$ alloy is in good agreement with those reported by Gregson et al. ${ }^{(21)}$.

Figure 4 shows dark field images of $\mathrm{Al}-\mathrm{Li}-$ $\mathrm{Cu}-\mathrm{Mg}-\mathrm{Zr}$ alloy observed by use of the $\mathrm{L}_{2}$ ordered spots in the as quenched state (a), after aging at $443 \mathrm{~K}$ for $6 \times 10^{3} \mathrm{~s}(\mathrm{~b})$, at $443 \mathrm{~K}$ for $1.8 \times 10^{5} \mathrm{~s}(\mathrm{c})$, and at $473 \mathrm{~K}$ for $6 \times 10^{4} \mathrm{~s}(\mathrm{~d})$, respectively. The as quenched alloy contains a uniform dispersion of very fine $\delta^{\prime}$-particles. The $\delta^{\prime}$-particles are of irregular shape in the as quenched state and tend to spheroidize as aging proceeds. This tendency is the same as that of Al-Li binary alloy. In the peak-aged (c) or over-aged (d) states, however, composite precipitates exhibiting characteristic dual con- 

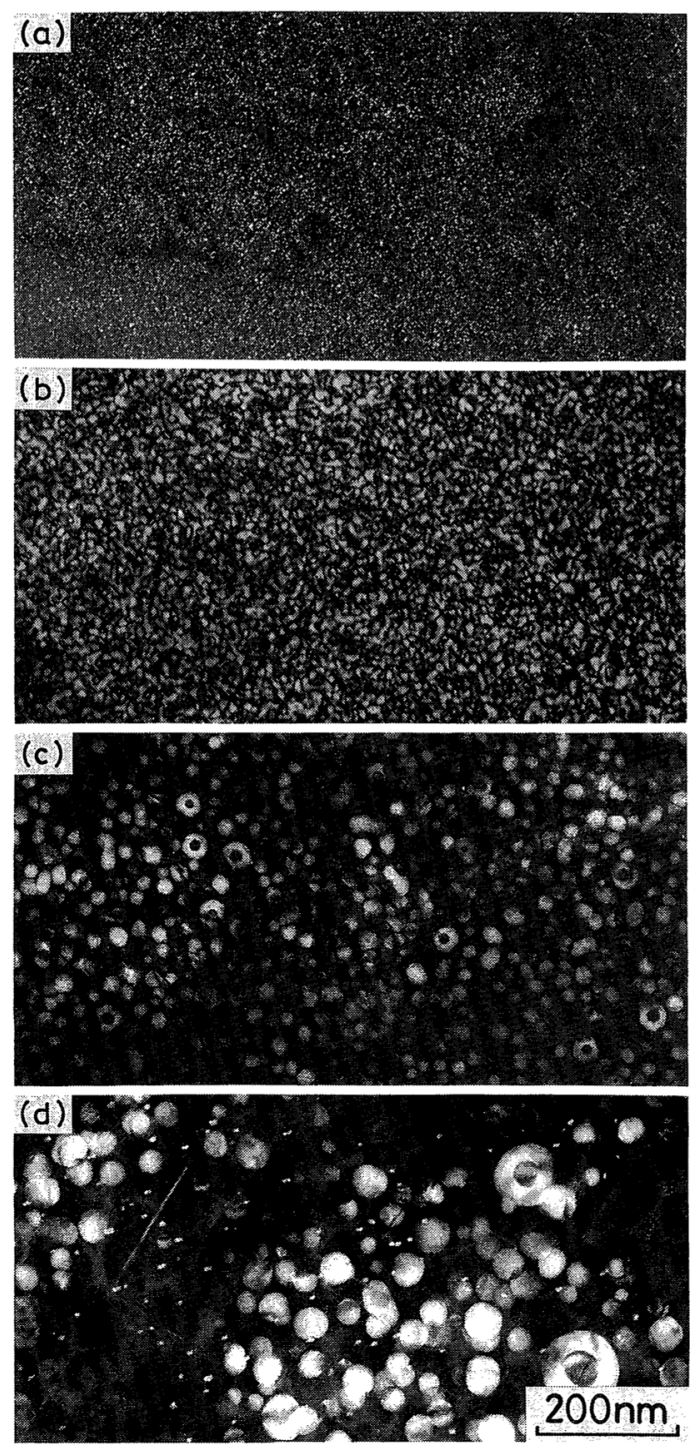

Fig. 4 Dark field images of $\mathrm{Al}-\mathrm{Li}-\mathrm{Cu}-\mathrm{Mg}-\mathrm{Zr}$ alloy. (a) As quenched, (b) aged at $443 \mathrm{~K}$ for $6 \times 10^{3} \mathrm{~s}$, (c) aged at $443 \mathrm{~K}$ for $1.8 \times 10^{5} \mathrm{~s}$ and aged at $473 \mathrm{~K}$ for $6 \times 10^{4} \mathrm{~s}$.

trast are observed. These have been shown to be $\delta^{\prime}$ surrounding an $\mathrm{Al}_{3} \mathrm{Zr}$ core ${ }^{(22)}$. The metastable $\mathrm{Al}_{3} \mathrm{Zr}$ particles with an $\mathrm{L}_{2}$ structure precipitate during solution treatment at $823 \mathrm{~K}^{(23)(24)}$, which can be observed by the strong Ashby-Brown ${ }^{(25)}$ lobe-type strain contrast in a bright field image in the as quenched specimen since the misfit between the metastable $\mathrm{Al}_{3} \mathrm{Zr}$ and the matrix is relatively large $(\sim+1 \%)^{(26)(27)}$. These $\mathrm{Al}_{3} \mathrm{Zr}$ particles are invisible in a dark field image of as quenched alloy as already reported ${ }^{(23)(24)}$. Shells of $\delta^{\prime}$ are formed around the $\mathrm{Al}_{3} \mathrm{Zr}$ particles during aging and as a results the $\mathrm{Al}_{3} \mathrm{Zr}$ particles become visible in the dark field image as shown in Fig. 4 (c) and (d). Only the diffraction spots from the $\mathrm{L}_{2}$ phase are observed during aging until the peak-aged condition at $443 \mathrm{~K}$. This result suggests that $\delta^{\prime}$ is the main phase contributing to the strength of the $\mathrm{Al}-\mathrm{Li}-\mathrm{Cu}-\mathrm{Mg}-\mathrm{Zr}$ alloy. In the over-aged condition, Fig. 4(d), the $\mathrm{S}^{\prime}$ phase $\left(\mathrm{Al}_{2} \mathrm{CuMg}\right)$ of needle-like shape is found along three $\langle 100\rangle$ directions of the matrix. In Fig. 4(d), the spot-like precipitates are the projection of the $S^{\prime}$ needles lying normal to the foil surface. The precipitation of $S^{\prime}$-phase is accelerated when the alloy is stretched before aging $^{(13)}$. However, only a small amount of $\mathrm{S}^{\prime}$-phase was detected in the peak-aged condition of the unstretched alloy. The $\mathrm{T}_{1}$-phase is also observed in the over-aged condition of the present alloy. The $\mathrm{L}_{2}$, superlattice spots in the selected area diffraction pattern of the overaged alloy become weak indicating that the $\delta^{\prime}$-phase is absorbed into the stable $\delta$-phase (AlLi) and/or $\mathrm{T}_{1}$-phase $\left(\mathrm{Al}_{2} \mathrm{CuLi}\right)$ during aging.

Figure 5 shows the morphologies of deformation induced dislocations in the $\mathrm{Al}-\mathrm{Li}-\mathrm{Cu}-$ $\mathrm{Mg}-\mathrm{Zr}$ alloy in the as quenched state (a), after aging at $443 \mathrm{~K}$ for $6 \times 10^{3} \mathrm{~s}(\mathrm{~b})$, at $443 \mathrm{~K}$ for $1.8 \times 10^{5} \mathrm{~s} \mathrm{(c)} \mathrm{and} \mathrm{at} 473 \mathrm{~K}$ for $6 \times 10^{4} \mathrm{~s} \mathrm{(d),} \mathrm{re-}$ spectively. The specimens were deformed $3 \%$ in compression at room temperature. In the specimens as quenched (a), under-aged (b) or aged nearly to peak strength (c), it is clear from the micrograph that the deformation induced dislocations move as pairs similarly to those in the Al-Li binary alloy. However, dislocations in the $\mathrm{Al}-\mathrm{Li}-\mathrm{Cu}-\mathrm{Mg}-\mathrm{Zr}$ alloy are more wavy even in the as quenched state (a) as compared to those in the binary Al-Li alloy in which dislocations are almost straight in the as quenched $\operatorname{state}^{(14)}$. In the peak-aged alloy (c), dislocations move mainly as single dislocations and dislocation loops formed by by-passing the precipitates are often observed. In the over-aged alloy (d), dislocations move as single dislocations and form tangles during deformation. 

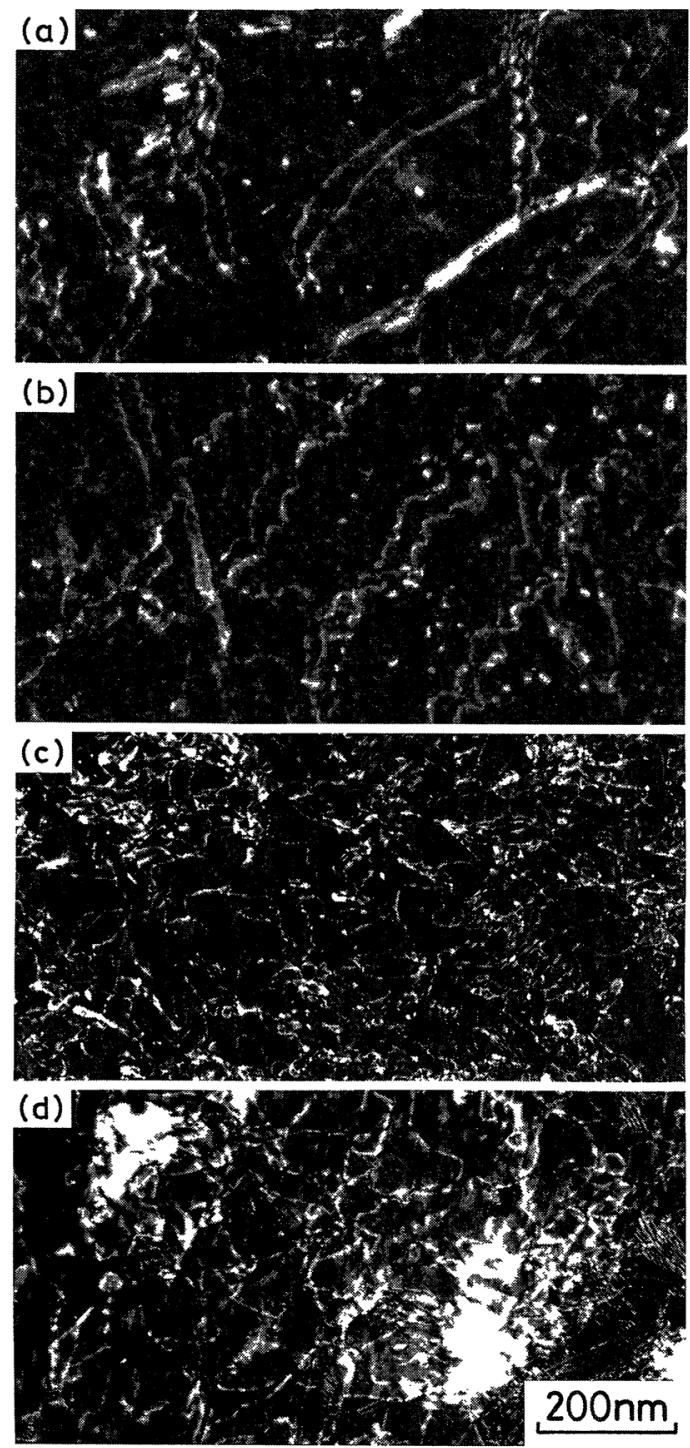

Fig. 5 (200) dark field images of $\mathrm{Al}-\mathrm{Li}-\mathrm{Cu}-\mathrm{Mg}-\mathrm{Zr}$ alloy. (a) As quenched, (b) aged at $443 \mathrm{~K}$ for $6 \times 10^{3} \mathrm{~s}$, (c) aged at $443 \mathrm{~K}$ for $1.8 \times 10^{5} \mathrm{~s}$ and (d) aged at $473 \mathrm{~K}$ for $6 \times 10^{4} \mathrm{~s}$. Specimens were deformed $3 \%$ in compression at room temperature.

\section{Temperature dependence of strength}

\section{(1) Stress-strain curves}

Figure 6 shows stress-strain curves obtained at temperatures between 77 and $523 \mathrm{~K}$ for the $\mathrm{Al}-\mathrm{Li}-\mathrm{Cu}-\mathrm{Mg}-\mathrm{Zr}$ alloy as quenched (a), under-aged (b), peak-aged (c) and over-aged (d) states, respectively. Although the stressstrain curves are smooth at $77 \mathrm{~K}$ at any aging

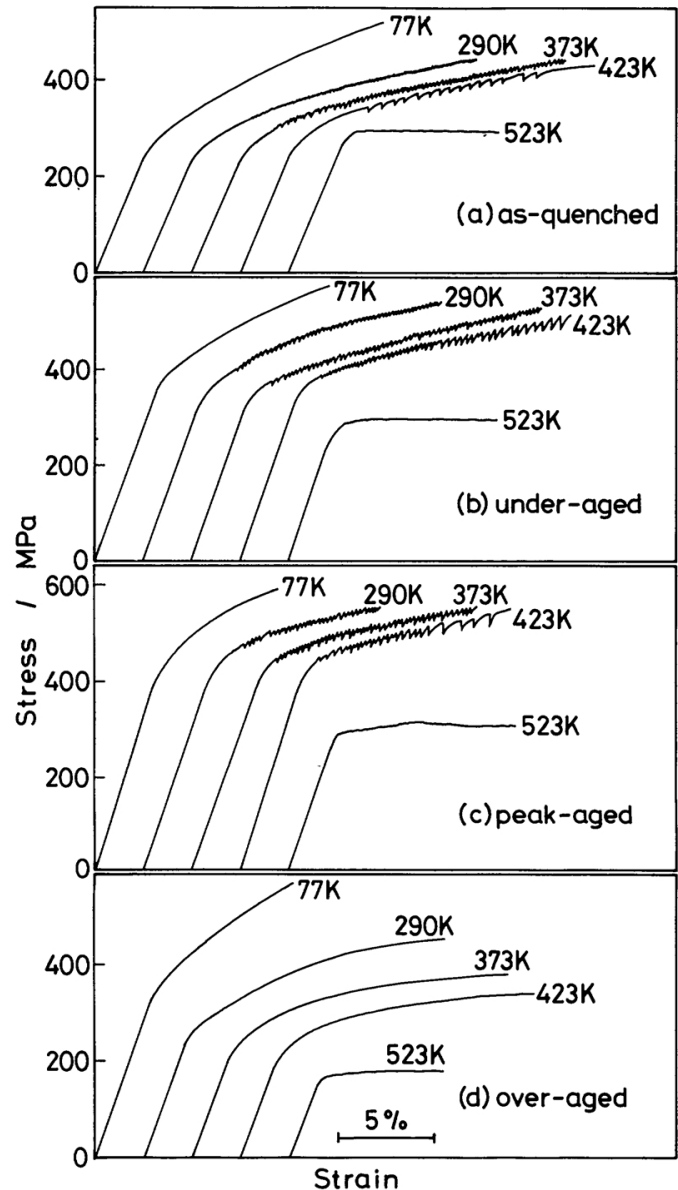

Fig. 6 The effect of testing temperature on the stressstrain curves of $\mathrm{Al}-\mathrm{Li}-\mathrm{Cu}-\mathrm{Mg}-\mathrm{Zr}$ alloy. (a) As quenched, (b) aged at $443 \mathrm{~K}$ for $6 \times 10^{3} \mathrm{~s}$ (under-aged), (c) aged at $443 \mathrm{~K}$ for $6 \times 10^{4} \mathrm{~s}$ (peak-aged) and (d) aged at $473 \mathrm{~K}$ for $6 \times 10^{4} \mathrm{~s}$ (over-aged). Specimens were deformed in compression at normal strain rate of $3.54 \times 10^{-4} \mathrm{~s}^{-1}$.

condition, those obtained for as quenched (a), under-aged (b) and peak-aged (c) states are serrated at testing temperatures between 290 and $423 \mathrm{~K}$. The amplitude of serration is increased with increasing temperature in this temperature range. The stress-strain curves obtained for the over-aged alloy are smooth at any testing temperature.

Wert and Wycliffe ${ }^{(28)}$ have observed the serration in the stress-strain curves of the similar alloy at the room temperature and attributed it to the presence of $\mathrm{Mg}$ and/or $\mathrm{Cu}$ atoms in solution, because the serrated deformation disappeared when the $\mathrm{S}^{\prime}$-phase $\left(\mathrm{Al}_{2} \mathrm{CuMg}\right)$ began to 
precipitate. However, it is clear that the serrated deformation of the $\mathrm{Al}-\mathrm{Li}-\mathrm{Cu}-\mathrm{Mg}-\mathrm{Zr}$ alloy is not attributable only to the presence of $\mathrm{Mg}$ and/or $\mathrm{Cu}$ in solution but also to the deformation mechanism in which dislocations move in pairs cutting the $\delta^{\prime}-\mathrm{L} 1_{2}$ ordered particles, since the stress-strain curves obtained for poly crystals $^{(29)}$ and single crystals ${ }^{(30)}$ of Al-Li binary alloys are also serrated.

(2) Temperature dependence of yield stress Figure 7 shows the variation of yield stress of the $\mathrm{Al}-\mathrm{Li}-\mathrm{Cu}-\mathrm{Mg}-\mathrm{Zr}$ alloy aged at $443 \mathrm{~K}$ as a function of aging time and testing temperature. As shown by the projection onto the bottom of the figure, the peak positions of the aging curves shift to the side of shorter aging time with increasing testing temperature. The same tendency was observed in the $\mathrm{Al}-\mathrm{Li}$ binary alloy ${ }^{(17)}$. Cross sections cut by planes perpendicular to the time axis and parallel to the temperature axis of Fig. 7 show the temperature dependence of yield stress at each aging condition. Figure 8 shows the temperature dependence of yield stress at each aging condition. For comparison, the results of $\mathrm{Al}-\mathrm{Li}$ binary alloy ${ }^{(16)}$ are also shown in the figure. A remarkable increase of yield stress of the as quenched alloy tested at temperatures above

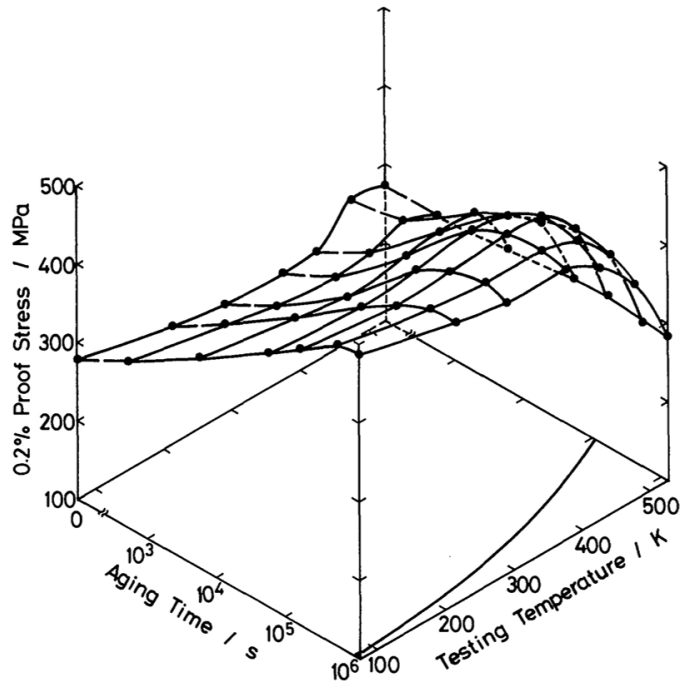

Fig. $7 \quad 0.2 \%$ proof stress-aging time-testing temperature diagram of $\mathrm{Al}-\mathrm{Li}-\mathrm{Cu}-\mathrm{Mg}-\mathrm{Zr}$ alloy aged at $443 \mathrm{~K}$ and tested in compression at normal strain rate of $3.54 \times 10^{-4} \mathrm{~s}^{-1}$.

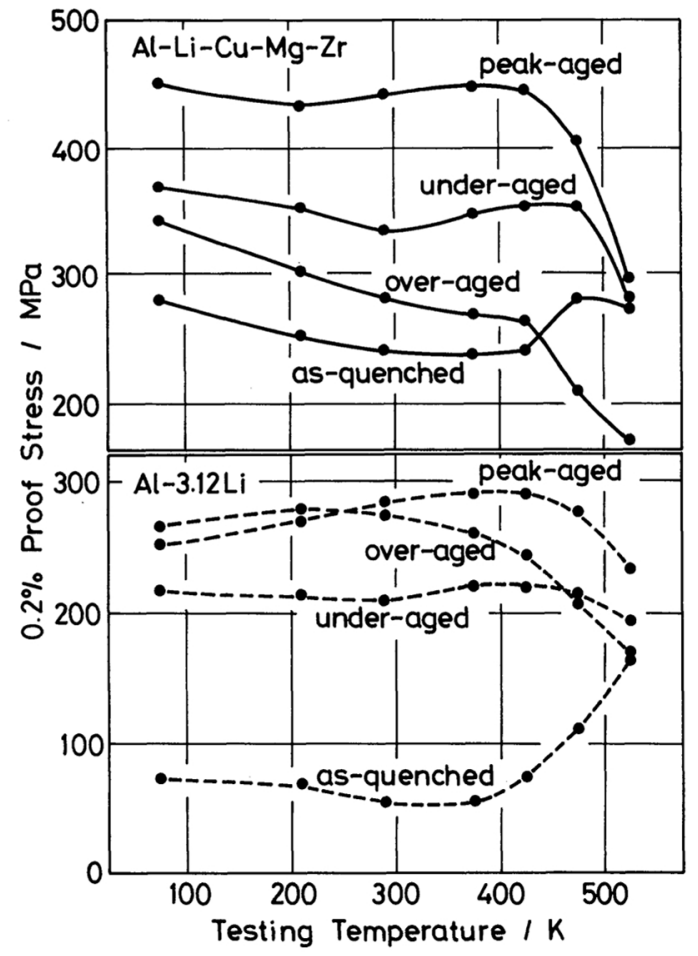

Fig. 8 Temperature dependence of $0.2 \%$ proof stress of $\mathrm{Al}-\mathrm{Li}-\mathrm{Cu}-\mathrm{Mg}-\mathrm{Zr}$ alloy. Dotted lines indicate $0.2 \%$ proof stress of Al-3.12 mass\% $\%$ i alloy.

$450 \mathrm{~K}$ is due apparently to the age hardening during testing. From Fig. 8, it is clear that the positive temperature dependence of yield stress appears in the temperature range from 290 to $450 \mathrm{~K}$ for the both alloys under-aged or aged nearly to its peak strength. Furthermore, the yield stress of $\mathrm{Al}-\mathrm{Li}-\mathrm{Cu}-\mathrm{Mg}-\mathrm{Zr}$ alloy increases remarkably with decreasing testing temperature from 290 to $77 \mathrm{~K}$. For the over-aged stage, the degradation of yield stress of the Al$\mathrm{Li}-\mathrm{Cu}-\mathrm{Mg}-\mathrm{Zr}$ alloy with increasing testing temperature is more distinguishable than that of the Al-Li binary alloy. Pridham et al..$^{(13)}$ have reported that the positive temperature dependence of yield strength of the alloy aged nearly to its peak strength appears only when the alloy was maintained at the testing temperature for $3.6 \times 10^{6} \mathrm{~s}$. The reason of the difference between the present result and that of Pridham et al. is not clear.

Figure 9 (a), (b), (c) and (d) show 200 dark field images of dislocations in the under-aged alloy deformed $3 \%$ in compression at $77 \mathrm{~K}$ (a), 

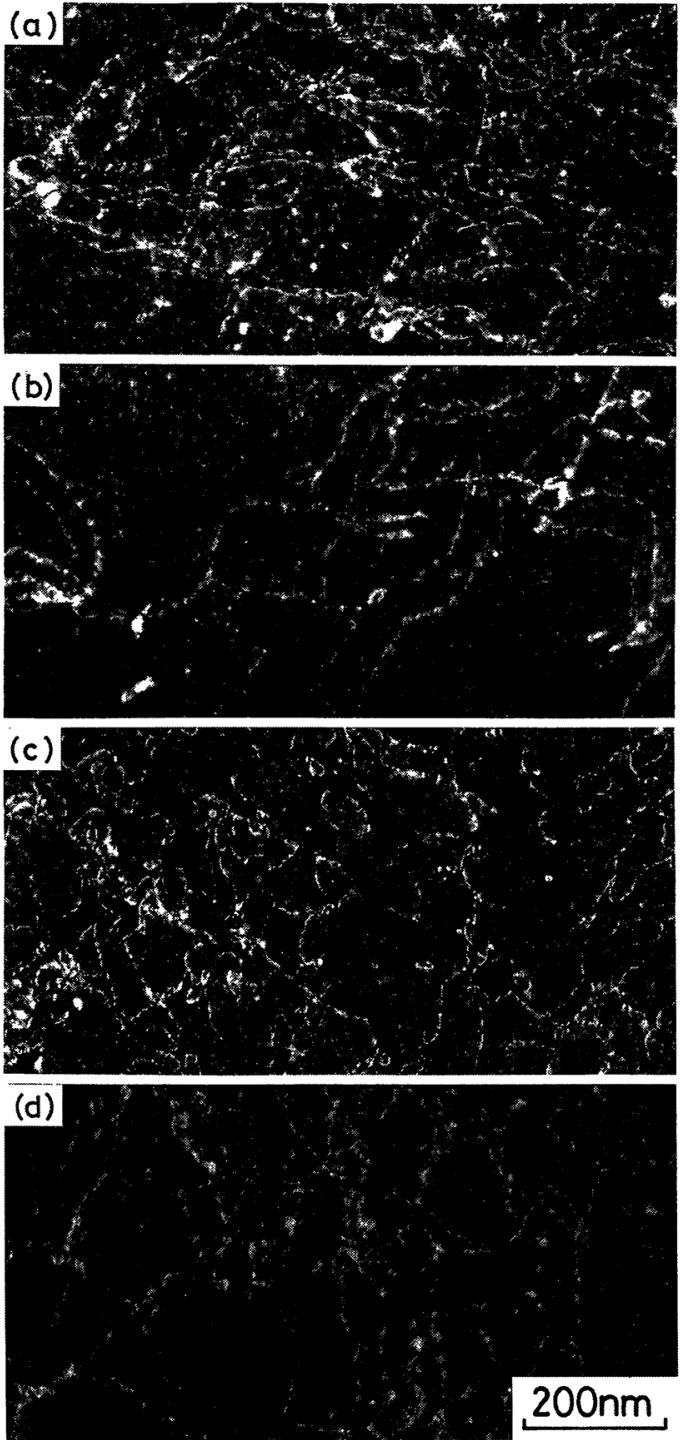

Fig. 9 (200) dark field images of Al-Li-Cu-Mg-Zr alloy aged at $443 \mathrm{~K}$ for $6 \times 10^{3} \mathrm{~s}$ and deformed $3 \%$ in compression at $77 \mathrm{~K}(\mathrm{a}), 373 \mathrm{~K}(\mathrm{~b}), 423 \mathrm{~K}$ (c) and $573 \mathrm{~K}$ (d).

$373 \mathrm{~K}$ (b), $423 \mathrm{~K} \mathrm{(c)} \mathrm{and} 523 \mathrm{~K}(\mathrm{~d})$, respectively. Dislocations move in pairs, when the alloy is deformed in the temperature range from $77 \mathrm{~K}$ (a) to $373 \mathrm{~K}$ (b). At $423 \mathrm{~K}$ (c), almost all dislocations move as single dislocations and many dislocation loops are observed. The deformation induced dislocations are completely single at $523 \mathrm{~K}(\mathrm{~d})$. This tendency is the same as that of Al-Li binary alloy ${ }^{(16)}$. However, the configuration of dislocations in the $\mathrm{Al}-\mathrm{Li}-\mathrm{Cu}-\mathrm{Mg}-\mathrm{Zr}$ alloy are more complex than those in the Al-Li binary alloy.

\section{Strain rate dependence of yield stress}

Figure 10 shows the variation of yield stress of the alloy (a) aged at $443 \mathrm{~K}$ for $6 \times 10^{3} \mathrm{~s}$ (under-aged), (b) aged at $443 \mathrm{~K}$ for $1.8 \times 10^{5} \mathrm{~s}$ (peak-aged) and (c) aged at $473 \mathrm{~K}$ for $6 \times 10^{4} \mathrm{~s}$ (over-aged), respectively. Dotted lines in the figure indicate yield stress of $\mathrm{Al}-3.12$ mass $\% \mathrm{Li}$ alloy for corresponding aging stages ${ }^{(17)}$. It is clear that the yield stress increases linearly with the logarithm of strain rate at temperatures above $473 \mathrm{~K}$.

For the under-aged alloy (a), the yield stress is almost independent of strain rate at $77 \mathrm{~K}$. In the temperature range from 290 to $423 \mathrm{~K}$, however, the yield stress decreases linearly with the logarithm of strain rate. That is to say, the yield stress of the alloy seems to have a characteristic negative strain rate dependence. This negative strain rate dependence of yield stress of the $\mathrm{Al}-\mathrm{Li}-\mathrm{Cu}-\mathrm{Mg}-\mathrm{Zr}$ alloy is more remarkable than that of the $\mathrm{Al}-\mathrm{Li}$ binary alloy ${ }^{(17)}$. Within the temperature range in which the negative strain rate dependence of yield stress appears, the positive temperature dependence of yield stress was observed as shown in Fig. 8 and the stress-strain curves were serrated as shown in Fig. 6(b). At testing temperatures above $473 \mathrm{~K}$, the yield stress increases linearly with the logarithm of strain rate.

For the peak-aged state (b) and the over-aged state (c), the yield stress is almost independent of strain rate at temperatures below 423 K. At temperatures above $473 \mathrm{~K}$, however, the yield stress increases linearly with the logarithm of strain rate and its strain rate dependence increases with increasing testing temperature. This result suggests that the deformation mechanism varies with increasing deformation temperature.

\section{Deformation mechanism of $\mathrm{Al}-\mathrm{Li}-\mathrm{Cu}-$ $\mathrm{Mg}-\mathrm{Zr}$ alloy}

As shown in Fig. 3, the yield strength of Al$\mathrm{Li}-\mathrm{Cu}-\mathrm{Mg}-\mathrm{Zr}$ alloy is higher by $150-200 \mathrm{MPa}$ than that of $\mathrm{Al}-\mathrm{Li}$ binary alloy over the aging conditions from the as quenched state to the 
(a) under-aged

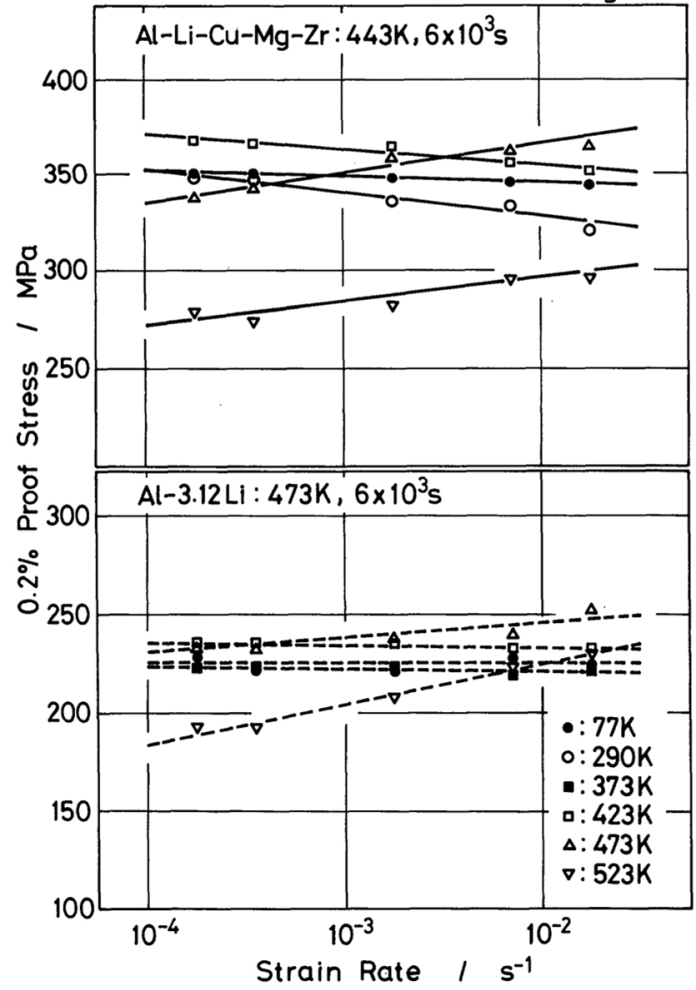

(c) over-aged

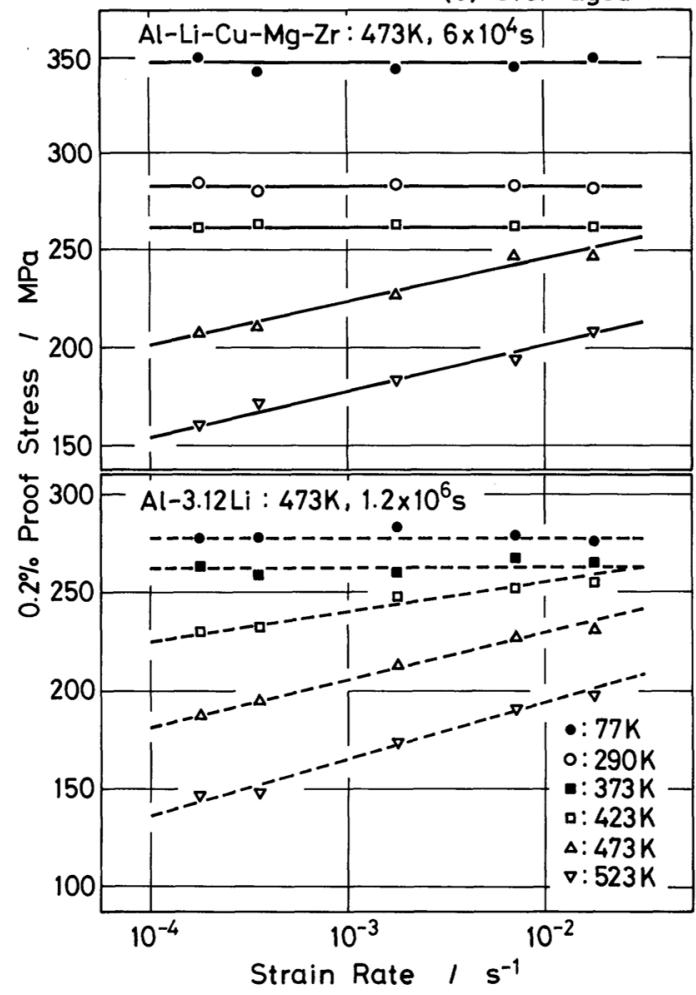

(b) peak-aged

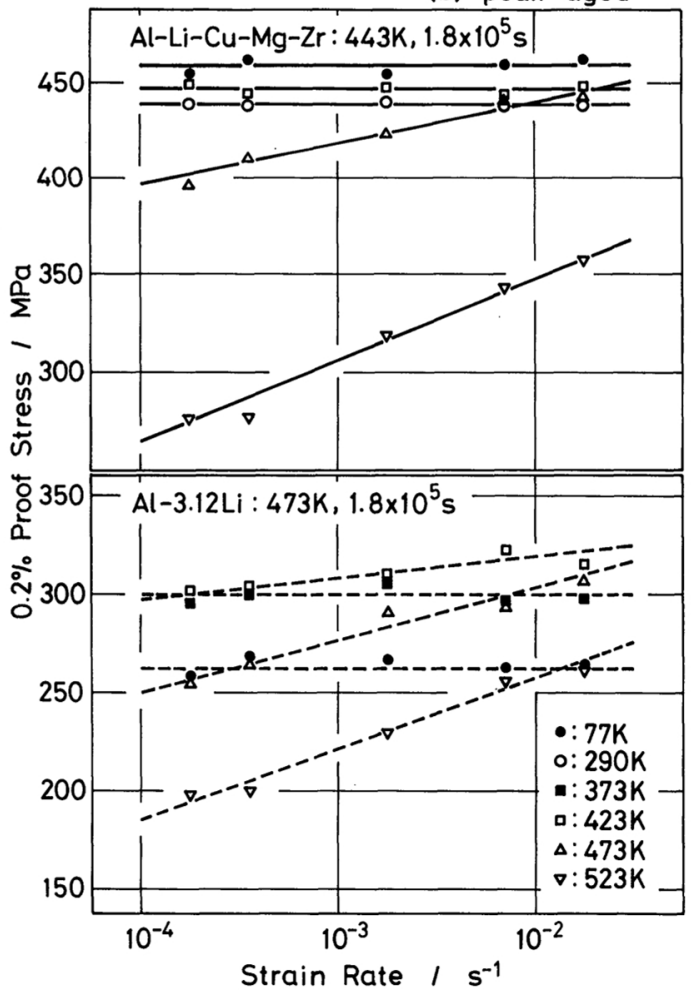

Fig. 10 The effect of strain rate on the $0.2 \%$ proof stress of $\mathrm{Al}-\mathrm{Li}-\mathrm{Cu}-\mathrm{Mg}-\mathrm{Zr}$ alloy (a) aged at $443 \mathrm{~K}$ for $6 \times 10^{3} \mathrm{~s}$ (under-aged), (b) aged at $443 \mathrm{~K}$ for $1.8 \times 10^{5}$ s (peakaged) and (c) aged at $473 \mathrm{~K}$ for $6 \times 10^{4} \mathrm{~s}$ (over-aged). Dotted lines indicate $0.2 \%$ proof stress of $\mathrm{Al}-3.12 \mathrm{mass} \% \mathrm{Li}$ alloy. 
peak-aged state. The strengthening mechanisms which should be responsible to the higher strength of the $\mathrm{Al}-\mathrm{Li}-\mathrm{Cu}-\mathrm{Mg}-\mathrm{Zr}$ alloy as compared to the Al-Li binary alloy can be summarized as follows: (1) strengthening due to grain refinement, (2) strengthening due to precipitates other than $\delta^{\prime}$-phase, and (3) solid solution strengthening by $\mathrm{Mg}$ and $\mathrm{Cu}$.

\section{(1) Strengthening due to grain refinement}

As shown in Fig. 1, the grain size of Al-Li$\mathrm{Cu}-\mathrm{Mg}-\mathrm{Zr}$ alloy is smaller than that of $\mathrm{Al}-$ $\mathrm{Li}$ binary alloy. The grain size of $\mathrm{Al}-\mathrm{Li}-\mathrm{Zr}$ ternary alloy is also small. From the difference of the strength of $\mathrm{Al}-\mathrm{Li}$ alloy and of $\mathrm{Al}-\mathrm{Li}-$ $\mathrm{Zr}$ alloy in the as quenched state, it is clear that the grain refinement provides an increase in yield stress of $30-40 \mathrm{MPa}$. The Al-Li-Cu$\mathrm{Mg}-\mathrm{Zr}$ alloy has smaller grain size than the $\mathrm{Al}-$ $\mathrm{Li}-\mathrm{Zr}$ alloy and contains many subgrain boundaries even after the solution treatment. Pridham et al. ${ }^{(13)}$ examined the $\mathrm{Al}-\mathrm{Li}-\mathrm{Cu}-\mathrm{Mg}$ alloy containing $\mathrm{Mn}$ instead of $\mathrm{Zr}$. The $\mathrm{Al}-\mathrm{Li}-$ $\mathrm{Cu}-\mathrm{Mg}-\mathrm{Mn}$ alloy has nearly equal grain size with the $\mathrm{Al}-\mathrm{Li}-\mathrm{Cu}-\mathrm{Mg}-\mathrm{Zr}$ alloy but is free from subgrain boundaries. From the strength difference between the as quenched $\mathrm{Al}-\mathrm{Li}-\mathrm{Cu}-$ $\mathrm{Mg}-\mathrm{Mn}$ and $\mathrm{Al}-\mathrm{Li}-\mathrm{Cu}-\mathrm{Mg}-\mathrm{Zr}$ alloys, the contribution of the subgrain boundaries to the strength of $\mathrm{Al}-\mathrm{Li}-\mathrm{Cu}-\mathrm{Mg}-\mathrm{Zr}$ alloy is estimated to be approximately $100 \mathrm{MPa}$. Consequently, the contribution to the strength of the alloy due to grain refinement including subgrain boundaries is approximately 100-130 $\mathrm{MPa}$. This value amounts to $50-70 \%$ of the difference (about $200 \mathrm{MPa}$ ) between the yield stress of the $\mathrm{Al}-\mathrm{Li}$ binary alloy and that of the $\mathrm{Al}-\mathrm{Li}-\mathrm{Cu}-\mathrm{Mg}-\mathrm{Zr}$ alloy in the as quenched state.

\section{(2) Strengthening due to precipitates}

Metastable $\mathrm{Al}_{3} \mathrm{Zr}, \mathrm{S}^{\prime}\left(\mathrm{Al}_{2} \mathrm{CuMg}\right), \mathrm{T}_{1}\left(\mathrm{Al}_{2} \mathrm{CuLi}\right)$ and $\delta$ phases, in addition to the $\delta^{\prime}$-phase, precipitate in the $\mathrm{Al}-\mathrm{Li}-\mathrm{Cu}-\mathrm{Mg}-\mathrm{Zr}$ alloy ${ }^{(8)-(10)}$. The metastable $\mathrm{Al}_{3} \mathrm{Zr}$ particles precipitate during the solution treatment and hardly grow during the subsequent aging treatment. It is obvious from Fig. 3 that the peak strength of Al-Li binary alloy is nearly equal to that of $\mathrm{Al}-\mathrm{Li}-\mathrm{Zr}$ alloy. This seems to in- dicate that the precipitation of $\mathrm{Al}_{3} \mathrm{Zr}$ has only a little influence on the yield strength of $\mathrm{Al}-\mathrm{Li}-$ $\mathrm{Cu}-\mathrm{Mg}-\mathrm{Zr}$ alloy but increases the strength and improves ductility of the alloy through the grain refinement and subgrain formation. Both the $\mathrm{T}_{1}$ and $\delta$ phases have almost no influence on the strength of the alloy aged nearly to the peak strength, because they precipitate only in the over-aged state. When the quenched alloy is stretched and subsequently aged, the S'phase precipitates preferentially on the dislocations and subgrain boundaries even in the early aging stage ${ }^{(13)}$. Consequently, the $S^{\prime}$-phase should contribute to the strength of the stretched alloy. However, when the alloy is aged without stretching, only a little amount of $\mathrm{S}^{\prime}$ phase precipitates in the peak-aged state. Therefore it should be clear that the $\mathrm{S}^{\prime}$-phase has little influence on the strength of the unstretched alloy. In addition, the existence of the paired dislocations in the as quenched and aged alloys indicates that the precipitation of $\delta^{\prime}$-phase plays main roles to the strength of the $\mathrm{Al}-\mathrm{Li}-\mathrm{Cu}-\mathrm{Mg}-\mathrm{Zr}$ alloy. The amount of age hardening of $\mathrm{Al}-\mathrm{Li}-\mathrm{Cu}-\mathrm{Mg}-\mathrm{Zr}$ alloy at the aging temperature of $443 \mathrm{~K}$ is about $200 \mathrm{MPa}$ and is about $120 \mathrm{MPa}$ at $473 \mathrm{~K}$. These amounts of age hardening are less than that of $\mathrm{Al}-\mathrm{Li}$ binary alloy which amounts to about $220 \mathrm{MPa}$ even at $473 \mathrm{~K}$. This also supports the conclusion that the precipitation of $\delta^{\prime}$-phase is the principal cause for the strengthening of the Al$\mathrm{Li}-\mathrm{Cu}-\mathrm{Mg}-\mathrm{Zr}$ alloy.

\section{(3) Solid solution strengthening}

The predominant features of the strength and the deformation behavior of the Al-Li$\mathrm{Cu}-\mathrm{Mg}-\mathrm{Zr}$ alloy as compared with the $\mathrm{Al}-\mathrm{Li}$ binary alloy can be summarized as follows: (a) the apparent increase of yield stress in the lower temperature range, (b) the negative strain rate dependence of yield stress in the temperature range in which the positive temperature dependence of yield stress appears, and (c) the increase of the amplitude of serration in stress-strain curves with increasing testing temperature from 290 to $423 \mathrm{~K}$. All these characteristics suggest that the solid solution strengthening by $\mathrm{Mg}$ and $\mathrm{Cu}$ contribute appreciably to the strength of the $\mathrm{Al}-\mathrm{Li}-\mathrm{Cu}-\mathrm{Mg}-$ 
$\mathrm{Zr}$ alloy. The yield stress of as quenched Al$\mathrm{Cu}-\mathrm{Mg}-\mathrm{Zr}$ reference alloy ingot in which $\mathrm{Li}$ and subgrain boundaries are absent is about $110 \mathrm{MPa}$. Since the contribution due to the grain refinement is approximately $30-40 \mathrm{MPa}$, the amount of solid solution strengthening due to $\mathrm{Cu}$ and $\mathrm{Mg}$ can be estimated to be $70-80$ $\mathrm{MPa}$ in the as quenched state. The contribution from the solid solution strengthening should decrease as the $\mathrm{S}^{\prime}$ and $\mathrm{T}_{1}$ phases start to precipitate.

\section{Conclusion}

(1) In the $\mathrm{Al}-\mathrm{Li}-\mathrm{Cu}-\mathrm{Mg}-\mathrm{Zr}$ alloy as quenched, under-aged or aged nearly to the peak strength, dislocations move in pairs when the alloy is deformed at $290 \mathrm{~K}$. In the over-aged alloy, dislocations move in single dislocations and tangle during deformation.

(2) For the alloy under-aged or aged nearly to its peak strength, the yield stress decreases with increasing testing temperature from 77 to $290 \mathrm{~K}$, and the positive temperature dependence of yield stress is observed in the temperature range from 290 to $450 \mathrm{~K}$. Within this temperature range, dislocations move in pairs cutting the $\delta^{\prime}-\mathrm{L} 1_{2}$ ordered particles. The yield stress decreases with increasing testing temperature above $450 \mathrm{~K}$, and dislocations move as single dislocations. For the over-aged alloy, the yield stress decreases monotonically with increasing testing temperature from 77 to $523 \mathrm{~K}$.

(3) The serrated yielding characteristic is observed for specimens as quenched, under-aged and aged nearly to the peak strength in the temperature range from 290 to $423 \mathrm{~K}$. The amplitude of serration increases with increasing testing temperature.

(4) At testing temperatures below $423 \mathrm{~K}$, the yield stress is almost independent of strain rate at peak-aged and over-aged stages. For the under-aged stage, the strain rate dependence of the yield stress is negative at the temperature range within which the positive temperature dependence of yield stress appears. At testing temperatures above $473 \mathrm{~K}$, the yield stress increases linearly with the logarithm of strain rate at any aging stage, and the strain rate dependence increases with increasing testing temperature.

(5) The principal contributions to the strength of unstretched $\mathrm{Al}-\mathrm{Li}-\mathrm{Cu}-\mathrm{Mg}-\mathrm{Zr}$ alloy are the precipitation strengthening by $\delta^{\prime}$ phase, the grain refinement including subgrain boundaries, and the solid solution strengthening by $\mathrm{Mg}$ and $\mathrm{Cu}$. The precipitation of metastable $\mathrm{Al}_{3} \mathrm{Zr}$ phase contributes to the strength of the alloy mainly through the grain refinement of the alloy.

\section{Acknowledgments}

This research was supported partly by the Grant-in Aid for Scientific Research from the Ministry of Education, Science and Culture, Japan (60550515). The Grant-in Aid from the Light Metal Educational Foundation, Inc. is also acknowledged.

\section{REFERENCES}

(1) M. Furukawa, Y. Miura and M. Nemoto: Bul. Japan Inst. Metals, 23 (1984), 172.

(2) T. H. Sanders, Jr. and E. A. Starke, Jr.: AluminumLithium Alloys, Met. Soc. AIME, (1981).

(3) T. H. Sanders, Jr. and E. A. Starke, Jr.: AluminumLithium Alloys II, Met. Soc. AIME, (1984).

(4) C. Baker, P. J. Gregson, S. J. Harris and C. J. Peel: Aluminium-Lithium Alloys III, The Inst. Metals, (1986).

(5) E. Kuramoto: Bul. Japan Inst. Metals, 14 (1975), 567.

(6) S. Takeuchi: Bul. Japan Inst. Metals, 18 (1979), 249.

(7) T. Suzuki: Bul. Japan Inst. Metals, 21 (1982), 19.

(8) M. Ahmad and T. Ericsson: Aluminium-Lithium Alloys III, Ed. by C. Baker, P. J. Gregson, S. J. Harris and C. J. Peel, The Inst. Metals, (1986), p. 509.

(9) K. Welpmann, M. Peters and T. H. Sanders, Jr.: ibid., p. 524.

(10) J. White, W. S. Miller, I. G. Palmer, R. Davis and T. S. Sain: ibid., p. 530.

(11) M. D. Ball and H. Lagace: ibid., p. 555.

(12) P. J. E. Bischler and J. W. Martin: ibid., p. 539.

(13) M. Pridham, B. Noble and S. J. Harris: ibid., p. 547.

(14) M. Furukawa, Y. Miura and M. Nemoto: Trans. JIM, 26 (1985), 225.

(15) M. Furukawa, Y. Miura and M. Nemoto: Trans. JIM, 26 (1985), 230.

(16) M. Furukawa, Y. Miura and M. Nemoto: Trans. JIM, 26 (1985), 414.

(17) M. Furukawa, Y. Miura and M. Nemoto: Trans. JIM, 27 (1986), 14.

(18) Y. Ueda, A. Matsui, M. Furukawa, Y. Miura and M. Nemoto: J. Japan Inst. Metals, 49 (1985), 562.

(19) J. M. Papazian, R. L. Schulte and P. N. Adler: Metall. Trans. A, 17A (1986), 635. 
(20) T. Sano, R. Nishihara, H. Yotsumoto, Y. Miura and M. Nemoto: Technology Reports of the Kyushu University, 56 (1983), 491.

(21) P. J. Gregson, C. J. Peel and B. Evans: AluminiumLithium Alloys III, Ed. by C. Baker, P. J. Gregson, S. J. Harris and C. J. Peel, The Inst. Metals, (1986), p. 516.

(22) P. J. Gregson and H. M. Flower: J. Mat. Sci. Letters, 3 (1984), 829.

(23) F. W. Gayle and J. B. VanderSande: AluminiumLithium Alloys III, Ed. by C. Baker, P. J. Gregson, S. J. Harris and C. J. Peel, The Inst. Metals, (1986), p. 376 .

(24) W. Stimson, M. H. Tosten, P. R. Howell and D. B.
Williams: ibid., p. 386.

(25) M. F. Ashby and L. M. Brown: Phil. Mag., 91 (1963), 1083.

(26) N. Ryum: Acta Metall., 17 (1967), 269.

(27) E. Nes: Acta Metall., 20 (1972), 499.

(28) J. A. Wert and P. A. Wycliffe: Scripta Metall., 19 (1985), 463.

(29) M. Furukawa, Y. Miura and M. Nemoto: 1986 Spring Meeting (98th convention) during April 1986 at Tokyo Univ., The Japan Inst. Metals, p. 77.

(30) T. Nakamura, T. Mori and M. Tamura: Symposium on Plastic Deformation at High Temperatures, Japan Light Metals Association, (1970), p. 64. 